\title{
DISTURBANCE AND RECOVERY OF VEGETATION AT THE SITES OF NUCLEAR ACCIDENTS IN ARCTIC YAKUTIA
}

\author{
Tatjana Koroleva, \\ Vladislav Petrovsky, \\ Olga Khitun \\ Komarov Botanical Institute, Russia
}

\begin{abstract}
Two peaceful underground nuclear explosions conducted in the middle of 1970-s in the Middle Siberia were followed by accidental release of radionuclides into the atmosphere. The condition of vegetation within the impacted area was examined in 2002. The study showed that normalization of radioactive situation and recovery of damaged vegetation did not happen during this period. Radioactive contamination resulted in either total or partial elimination of the vegetation. Four zones according to the degree of disturbance were distinguished. Patterns of recovery are shown: some local shrubs are the most active colonizers, whereas reestablishing of larches occurs very slowly. Low rates of recovery can be explained by rather bad natural condition for reproduction of larch, by presence of dead lichen cover which prevents germination of seeds and possibly low microbial and fungal activity caused by radiation. Removal of heavily contaminated forest litter and sawing of local grasses and herbs may accelerate the rate of vegetation recovery.
\end{abstract}

\section{KEYWORDS}

Release of radionuclides; radioactive contamination; Yakutia; northern taiga; vegetation; recovery.

\section{INTRODUCTION}

Accidents followed by the radioactive releases may stipulate severe and long-term changes in the ecosystems adjacent to such locations. Such catastrophic event as Chernobyl accident (1986) is well-known throughout the world. Its consequences are studied in detail and gave information about the effects of radiation on ecosystems in the moderate climate zone [1]. The effects of radiation on Arctic ecosystems is less documented, therefore our data obtained in the Arctic East Siberia where larch forest was killed by accidental atmospheric release of radioactivity can contribute to studying this problem.

Twelve peaceful underground nuclear explosions (mainly for the purpose of mining industry) were conducted in different districts of Yakutia (Middle Siberia) in the period from 1974 till 1978. Two explosions ("Kraton-3", $40 \mathrm{~km}$ E from the settlement of Aikhal, on the bank of the Markha river, 65854' N, 112818' E, made in 1978 for seismic sounding of the Earth's crust and "Crystal", $2.5 \mathrm{~km}$ from the town of Udachnui, 65830' N, 112830' E, made in 1974 with the purpose to construct a reservoir dam for the mining enterprise) were followed by 
accidental release of radioactive substances into the atmosphere and radioactive contamination of the surroundings. Primary technical re-cultivation at "Kraton-3" epicenter was done in 1981: contaminated top-soil, vegetation and equipment were collected and buried in a pit excavated near the mouth of the bore-hole. At the site of "Crystal" explosion technical re-cultivation was carried out in 1992 and the created ground mound and the central crater were covered by barren rocks from nearby carrier. Some of the key radionuclides dispersed by "Kraton-3" and "Crystal" release were ${ }^{137} \mathrm{Cs},{ }^{239.240} \mathrm{Pu},{ }^{90} \mathrm{Sr},{ }^{241} \mathrm{Am}$. The power of gamma-radiation dose in affected areas is on average 3-4 times higher than the natural background [2]. There were rather many different investigations at these sites and measurements of radiation levels were hold repeatedly in the period 1990-2003 by different institutions [3, 4]. We participated in the field work in July of 2002 together with the colleagues from Research Institute of Radiation Hygiene and V.G. Khlopin's Radium Institute. Aim of our study was to estimate the condition of the vegetation at the contaminated sites and its potential for self-recovery.

\section{MATERIALS AND METHODS}

\subsection{Study area}

The area of investigations is located at the Vilui plateau, close to the northern boundary of the northern taiga zone and Polar circle. The plateau is dissected by several rivers into gradually sloping low hills with an average relative altitude of about $200-400 \mathrm{~m}$. Climate is extremely continental, mean January temperature is $-13^{\circ} \mathrm{C}$, (minimum is $-41^{\circ} \mathrm{C}$ ) and mean July temperature is $+15^{\circ} \mathrm{C}$. Soil is mainly sod-carbonate with slightly alkaline $\mathrm{pH}(7.5-8.45)$ and high proportion of clay [5].

\subsection{Background vegetation}

Sparse larch forests (woodlands) of Larix gmelinii with well-developed dwarf-shrub and lichen layers predominate in the area. Floristic compound of such communities is relatively poor and constant along the whole profile from bottom to top of the hills. Low shrubs (Salix boganidensis, Betula exilis, Potenilla fruticosa. Spiraea media) grow in understory, dwarfshrubs (Arctous erythrocarpa, Vaccinium uliginosum. Salix saxatilis, Dryas punctata) and sedges form the field layer, lichens (Cladonia arbuscula, Cladonia rangiferina, Cladonia uncialis, Cetraria cucullata. Cetraria islandica, Cladonia gracilis) and few mosses (Ditrichum flexicaule, Hylocomium splendens, Rhytidium rugosum. Tomentypnum nitens) form thick bottom layer. Larch crones density is $0.1-0.3$, height of trees is $6-10 \mathrm{~m}$ Such forests represent a stable ecosystem with maximal age of living trees about 200-250 years. Along with the forests there are also some intra-zonal vegetation occupying smaller areas: willow copses, meadows, riparian. Presence of calcicolous species as well as meadow-steppe and forest-steppe species (Scorzonera radiata, Arctous erythrocarpa, Dryas crenulata, Kobresia filifolia, Pedicularis triste) distinguish the flora of this region from other northern taiga floras in Western or Eastern Siberia.

\subsection{Contaminated area}

Cigar-shaped contaminated area has limited dimensions. At "Kraton-3" site it is a belt ca $400 \mathrm{~m}$ breadth and ca $5 \mathrm{~km}$ long oriented from SE to NW as the radioactive cloud moved. This territory is marked by the big amount of dead trees, so called "dead forest". At "Crystal" site damaged area is significantly smaller, ca. $1.5 \mathrm{~km}$ long. But the explosion itself and protecting "sarcophagus" caused some water-logging at a local scale. Increased concentrations of longliving artificial radionuclides $\left({ }^{137} \mathrm{Cs},{ }^{239.240} \mathrm{Pu},{ }^{90} \mathrm{Sr},{ }^{241} \mathrm{Am}\right)$ were found in all components of 
the ecosystem. At "Kraton-3" concentration of radiocesium in top-soil varied from 140 to $87000 \mathrm{~Bq} / \mathrm{kg}$ in different parts of the area, it was practically in the same range also in lichens, and at "Crystal" it was 540-2100 Bq/kg. Background concentrations at both sites were 23$61 \mathrm{~Bq} / \mathrm{kg}$ [3]. Concentration of radiostrontium in top-soil was $1100-190000 \mathrm{~Bq} / \mathrm{kg}$ at "Kraton-3" and 240-800 Bq/kg at "Crystal", background at both - 13-97 Bq/kg. At "Crystal" site contamination with ${ }^{60} \mathrm{Co}$ and ${ }^{241}$ Am were notable [3].

\subsection{Methods}

We used the lethal effects observed on larches and terricolous lichens as the major criteria for evaluation of the primary damage of the forest ecosystem. Although more than 20 years have passed since the initial injury of the forest, damage and alteration could be easily identified during aerial and terrestrial surveys. Geobotanical relevès were made at the sample plots in different parts of contaminated area; all plant species and their visually estimated abundance were recorded. Morphometric parameters of trees and shrubs were measured both in background and in disturbed sites. All radiometrical measurements of collected during the expedition samples were made by our colleagues from Research Institute of Radiation Hygiene and V.G. Khlopin's Radium Institute and published in open press [3, 4, 6], below we refer to their data.

\section{RESULTS}

According to the level of disturbance we divide the contaminated area into 4 zones.

1) Re-cultivation zone with total destruction of the vegetation cover and top-soil. Its area_is ca 34000 mé. Within the radius $200-300 \mathrm{~m}$ from the mouth of the bore-hole in the central part of the trace all vegetation and the top-soil were removed in the process of re-cultivation. Radiometric measurements of the soil probes taken in this part showed the highest concentrations of ${ }^{137} \mathrm{Cs}-6900 \mathrm{kBqm}^{-2}$. We observed in this zone natural re-vegetation of bare gravel-loamy ground due to the diaspore-rain with the local flora species. Re-vegetation occurs very slowly, 20 years after the explosion only ca $50 \%$ of the surface is covered by plants. In the soil profile absence of upper horizons (taken away during the recultivation) is notable but we has recorded also the formation of well defined humus horizon. Shrubs and herbs spread here more active than mosses and lichens. Potentilla fruticosa, Salix boganidensis, Arctous erythrocarpa, Dryas punctata, Festuca ovina, Parnassia palustris, Primula borealis are among the first and most active colonizers.

2) Zone of the dead vegetation cover - that is the belt of dead forest standing around the recultivation zone for ca $1 \mathrm{~km}$ along the trace. Size of the area is about $16000 \mathrm{~m}^{2}$. Formerly the highest levels of soil contamination were recorded in this zone, near the NE boundary of the recultivation zone. All vegetation layers died there, the majority of dead trees are standing vertically but without bark. There are many dead plant remnants in this zone but the original litter layer is completely absent. Fragments of moss turf survived near the stems of the dead trees. Now secondary vegetation is re-growing intensively this zone - shrubs and herbs are actively spreading here. Salix saxatilis, Salix boganidensis, Betula exilis, Potentilla fruticosa are dominating and may reach up to $1 \mathrm{~m}$ high. Single seedlings and saplings of larch (less than $0.5 \mathrm{~m}$ height) were recorded. In the soil profile all horizons are intact except for the $\mathrm{A}_{0}$. On the bare ground spots pioneer communities of mosses (Campyllium polyganum, Tortula fiagilis, Polytrichum juniperinum ) started to establish, so restoration of moss-lichen layer is in the very beginning. 
Comparisons of the concentration of radionuclides in the probes taken from bark and wood of dead larches and from above ground parts and roots of young larch saplings in this zone showed that concentrations of ${ }^{137} \mathrm{Cs},{ }^{239.240} \mathrm{Pu},{ }^{60} \mathrm{Co}$ in the bark of dead trees are dozen times higher than those in the wood, whereas concentrations of the same radionuclides in living trees were much higher than in dead (Table 1). Interestingly, that concentrations of ${ }^{137} \mathrm{Cs}$ in the dead wood in the most contaminated part at Kraton-3 site was almost 370 times lower than in the $30-\mathrm{km}$ zone of Chernobyl accident [6]. Concentrations of radionuclides decrease to the periphery of the radioactive trace. Concentrations of ${ }^{137} \mathrm{Cs},{ }^{239.240} \mathrm{Pu}$ and ${ }^{60} \mathrm{Co}$ in the roots of young larch trees were dozens times higher than concentration in the roots of the dead trees. High concentrations of ${ }^{239.240} \mathrm{Pu}$ in the roots of young Larix gmelinii, Betula exilis and Potentilla fruticosa show that these isotopes existing in chelat complexes in top soil are adsorbing by the root system [6].

At the site of "Crystal" explosion damage to vegetation was less and two above mentioned zones are absent, but the following two are present at both sites, at "Crystal" zone 3 starts directly from the protecting sarcophagus.

3) Zone of the survived lower layers - is located further away along the radioactive trace and characterized by $100 \%$ lethality of adult larches, but survival of $95 \%$ of the lichen-moss cover and occupies the biggest square, its length is $3-5 \mathrm{~km}$. Trees are dead here, but shrub-, dwarfshrub- and moss-lichen layers survived, probably they were partly damaged but by now they have completely recovered functionally. Compare to the background communities in the zone 3 we observed the increased amount of local pioneer species (probably because of less competition in absence of trees). No signs of restoration of trees (neither seedlings, nor samplings) were recorded.

Table 1. Concentration of radionuclides in dead and living trees and shrubs at Kraton-3 site. (Compiled after: [6])

\begin{tabular}{|c|c|c|c|c|}
\hline \multirow[t]{2}{*}{ Place of sampling } & \multirow[t]{2}{*}{ Object } & \multicolumn{3}{|c|}{$\begin{array}{l}\text { Radionuclides } \\
\text { concentration, } \mathrm{Bq} / \mathrm{kg}\end{array}$} \\
\hline & & ${ }^{137} \mathrm{Cs}$ & $\begin{array}{l}239.240 \\
\mathrm{Pu}\end{array}$ & ${ }^{60} \mathrm{Co}$ \\
\hline $\begin{array}{l}\text { Boundary: recultivation zone / zone } \\
\text { of totally damaged vegetation cover }\end{array}$ & $\begin{array}{l}\text { Dead larch bark } \\
\text { Dead larch wood }\end{array}$ & $\begin{array}{c}352 \\
14\end{array}$ & $\begin{array}{c}5.1 \\
0.28\end{array}$ & $\begin{array}{l}1.4 \\
\leq 0.3\end{array}$ \\
\hline $\begin{array}{l}1.5 \mathrm{~km} \text { away from epicenter, } \\
\text { transitional zone }\end{array}$ & Roots of dead larches & 53 & 0.86 & $\leq 0.7$ \\
\hline $\begin{array}{l}\text { Zone of totally damaged cover, } 40 \mathrm{~m} \\
\text { E from recultivation zone }\end{array}$ & $\begin{array}{l}\text { Young larch, } \\
\text { aboveground } \\
\text { roots }\end{array}$ & $\begin{array}{l}5100 \\
4700\end{array}$ & $\begin{array}{l}44 \\
28\end{array}$ & $\begin{aligned} & 5 \\
\leq & 3.4\end{aligned}$ \\
\hline $\begin{array}{l}\text { Boundary: recultivation zone / zone } \\
\text { of totally damaged vegetation cover }\end{array}$ & $\begin{array}{l}\text { Betula exilis, } \\
\text { aboveground, } \\
\text { roots }\end{array}$ & $\begin{array}{c}940 \\
1860\end{array}$ & $\begin{array}{l}0.54 \\
25.8\end{array}$ & $\begin{aligned} & 2.4 \\
\leq & 6.7\end{aligned}$ \\
\hline $\begin{array}{l}\text { Boundary: recultivation zone / zone } \\
\text { of totally damaged vegetation cover }\end{array}$ & $\begin{array}{l}\text { Potentilla fruticosa, } \\
\text { aboveground, } \\
\text { roots }\end{array}$ & $\begin{array}{c}210 \\
2480\end{array}$ & $\begin{array}{c}0.96 \\
52\end{array}$ & $\begin{aligned} & 1 \\
\leq & 6.0\end{aligned}$ \\
\hline
\end{tabular}

4) Transitional zone - that is a narrow belt (20-40 m width) between "dead forest" and surrounding it normal, background larch forest. Compare to zone 3 there are a certain amount 
(ca.10-30\%) of trees here which survived after the explosion. Some trees had morbidity effects (e.g. partial loss of needles, dryness of the main branches and apexes). Dead trees in this zone still have some bark. Interstingly, there are epiphitic lichens on the trunks and branches of some trees, this may mean that they died in this zone much later than in zones 2 or 3 because of lesser levels of radio-active contamination, but the process of dying off is ongoing and therefore the square of the transition zone is growing slowly, but it is difficult to prove without repeating monitoring.

The state of Larix gmelinii in the background communities shows that it is not growing at its ecological optimum here, trees look rather oppressed - short branches, narrow crones, replacement of apical shoots during the growth, shorter needles, lower trunks and smaller diameter (Table 2). This partly explains the low rates of tree re-establishment in the deteriorated area.

Table 2. Morphometric characteristic of Larix gmelinii in the area contaminated by the release of articficial radionuclides after "Kraton-3" underground explosion.

\begin{tabular}{cccccc}
\hline Zone & Age & Condition & $\begin{array}{c}\text { Deight, } \\
\text { cm }\end{array}$ & $\begin{array}{c}\text { Diameter of } \\
\text { trunk, cm }\end{array}$ & $\begin{array}{c}\text { Width of } \\
\text { crone, cm }\end{array}$ \\
\hline $\begin{array}{c}\text { Background } \\
\text { Background }\end{array}$ & 108 & Alive & 980 & 15.5 & 280 \\
4 & 114 & Alive & 720 & 12 & 220 \\
4 & 136 & Alive & 830 & 12.5 & 170 \\
4 & 104 & Alive & 380 & 6 & 60 \\
3 & 85 & Dead & 650 & 8.5 & 100 \\
3 & 110 & Dead & 600 & 8 & 120 \\
2 & 100 & Dead & 480 & 7 & 110 \\
2 & 125 & Dead & 615 & 11 & 140 \\
Background & 93 & Dead & 520 & 8 & 180 \\
4 & 33 & Alive & 110 & 2.3 & 45 \\
4 & 28 & Alive & 47 & 1.5 & 35 \\
3 & 21 & Alive & 86 & 1.5 & 45 \\
\hline
\end{tabular}

Living trees in the background communities are usually 20-40 years younger than trees of the same height at the contaminated area. 12-16 years old plants predominate among the shrubs both in disturbed and background communities, they established after the accident. Though at the top of the hill within the zone 3, age of Salix jenisejense was 21-24 years, definitely it survived after the impact radioactive contamination. The reason for little amount of seedlings and saplings of larches may be low seed production and low viability of seeds. Another reason for slow establishment of trees can be the presence of dead lichen cover in zones 2 and 3 , which prevent the melting of top-soil and re-vegetation of these sites by other plants. 


\section{CONCLUSIONS}

Effect of radioactive contamination manifested itself in either total (zone 1,2) or partial elimination (zone 3,4) of the vegetation. Throughout the whole area influenced by the radioactive contamination re-vegetation occurs only fragmentary and at very low rate. The complete recovery of the ecosystem of moss-lichen larch woodland can occur only after 100120 years, when the new generation of larch will form a well developed tree layer. At the sites deteriorated by fires in the same region we observed much more intensive processes of recovery. Very slow re-vegetation at Kraton-3 site can be caused by the weakening of fungi, bacterial and algae parts of the ecosystem caused by the radiation. Low rates of decomposition of dead wood and mineralization of organic litter prove this suggestion. In the zone of recultivation where contaminated ground was removed the rate of recovery is lower than in the zone with intact dead vegetation. High vitality and active spreading of the population of Potentilla fruticosa in the contaminated zones attracts special attention. In the natural communities the role of this shrub was negligible. Detailed study on the sustainability of this species to radiation can give interesting results. Though this was only pilot study, one practical recommendation can be given directly - removal of heavily contaminated dead lichens and forest litter and sawing of seeds of local grasses and herb will accelerate the recovery.

\section{ACKNOWLEDGEMENT}

This work was supported by the Russian Fundamental Science Foundation (project 05-0449583)

\section{REFERENCES}

[1] Andersson, K.G and Roed, J., 2006. Estimation of doses received in a dry-contaminated living area in Bryansk Region, Russia, since the Chernobyl accident. J. Environ. Radioact., 85 (2-3), 228-240.

[2] Kasatkin, V.V., Iljichev, V.A., Mjasnikov, K.V., Klishin, V.I., Mamonov, B.P. 2004. The status of radiation safety at the objects of peaceful nuclear explosions within the territory of the Sakha Republic (Yakutia). In: Radiation safety of the Republic of Sakha (Yakutia). Materials of the II Republican Conference, December 16-18, 2003, Yakutsk, pp. 82-100. (in Russian)

[3] Ramzaev V.P., V.Yu.Golikov, A.C. Mishin, I.G.Travnikova, M.V.Kaduka, O.S.Kravtzova, G.ya.Bruk, G.N. Kaidanovskii, L.A. Basalaeva, A.D. Gedeonov, Yu.V. Bulatenkov, V.V. Petrovskii, T.M. Koroleva, P. Strand, J. Brown. Modern radiatiactivehygienic situation in the region of peaceful underground nuclear explosions "Kraton-3" and "Crystal" at the territory of the Republic of Sakha (Yakutia). In: Radiation safety of the Republic of Sakha (Yakutia). Materials of the II Republican Conference, December 16-18, 2003, Yakutsk, pp.123-133 (in Russian)

[4] Gedeonov, A. D., Petrov, E.R., Alexeev, V.G., Kuleshova, I.N., Savopulo, M.L., Burtsev, I.S., Shkroev, V.Yu, Arkhipov, V.I., 2002. Residual radioactive contamination at the peaceful underground explosion sites "Craton-3" and "Crystal" in the Republic of Sakha (Yakutia). J. Environ. Radioact. 60, pp. 221-234.

[5] Averina, I.M., Agapitov, V.G., Doronina, N.A.e, 1962. Northern Yakutia: physicalgeographical characteristics. Works of Arctic and Antarctic Research Institute. V.236. 280 pp. (in Russian) 
[6] Gedeonov, A.D., Burtzev, I.S., Petrov, E.P., Shkroev, V.Y. , 2004 . Study of concentrations of $\mathrm{Pu}-239,240$ and other gamma-radiating radionuclides in the larches and trees at "Kraton-3" site. In: Radiation safety of the Republic of Sakha (Yakutia). Materials of the II Republican Conference, December 16-18, 2003, Yakutsk, pp.193-204. (in Russian) 